\title{
Qualifications and ethics education: the views of ICT professionals
}

\author{
Yeslam Al-Saggaf \\ Charles Sturt University \\ yalsaggaf@csu.edu.au
}

Oliver K. Burmeister

Charles Sturt University

\author{
Michael Schwartz \\ RMIT University
}

\section{Abstract}

Do information and communications technology (ICT) professionals who have ICT qualifications believe that the ethics education they received as part of their ICT degrees helped them recognise ethical problems in the workplace and address them? If they do, are they also influenced by their personal ethics? What else helps them recognise ethical problems in the workplace and address them? And what are their views in relation to the impact of ethics education on professionalism in the ICT workplace? A quantitative survey of 2,315 Australian ICT professionals revealed that participants who reported having various levels of qualifications found ethics education or training, to a small degree, helpful for recognising ethical problems and addressing them; although it is those with Non-ICT qualifications, not those with ICT degrees, who were influenced more by ethics education or training. This suggests that educators need to consider how to better prepare ICT graduates for the workplace challenges and the types of situations they subsequently experience. The survey also found that participants who reported having various levels of qualifications were not influenced by their personal ethics or indeed any other factor making ethics education or training important for developing professionalism. The quantitative survey was followed by qualitative interviews with 43 Australian ICT professionals in six Australian capital cities. These interviews provided further empirical evidence that ethics education is crucial for enabling ICT professionals to recognise ethical problems and resolve them and that educators need to consider how to better prepare ICT graduates for the types of moral dilemmas that they are likely going to face in the workforce.

Keywords: Professional ethics, personal ethics, IT courses, industry certification and ethical awareness.

\section{Introduction}

Professional ethics in business have been explored from various perspectives. Often the failures are highlighted (Bernoth, Dietsch, Burmeister, \& Schwartz, 2014; Bull \& McLean, 2007; Gotterbarn \& Miller, 2009), although some literature also shows positive exemplars of professionalism (Hedström, 2007; Rogerson, Weckert, \& Simpson, 2000). Within ICT there have been attempts to improve professional ethics, including a focus on values (Burmeister, 2010, 2012; Manders-Huits, 2010; Venable et al., 2011), codes of professional conduct (Berleur et al., 2004; Bowern, Burmeister, Gotterbarn, \& Weckert, 2006; Burmeister, 2000; Fawkes, 2014), as well as wider work on licensing, certification, adherence to international standards, and more (Dodig-Crnkovic \& Horniak, 2005; WSIS+10, 2014).

Professional ethics in ICT is part of a wider focus on business ethics which since its inception in the early 1980 s has been plagued by disputes as to its soundness (Drucker, 1981). Indeed, some researchers have insisted that with regard to business ethics nothing "meaningful" (Hill, 1995, p. 585) could ever be said due to a fundamental problem. Namely, that we need to be able to first discuss ethics in order to be able to discuss business ethics: and discussing ethics required a meaningful moral discourse which remains highly problematic. Following Hill this 
was so as for many "moral words and propositions make no sense, or are meaningless" (1995, p. 588). This, Hill argued, made it close to impossible "to talk about ethics" (1995, p. 589). In fact not only did it render such talk impossible. It also, he insisted, had a further consequence: it made any agreement as to the moral truth impossible. This underlying reality is revealed by the responses of our ICT interviewees who often agitated for different initiatives in countering unprofessional behaviour. This is certainly heightened by the difference between what is taught to future ICT professionals and the reality of what they ultimately experience in their workplaces.

Hill however identifies an even larger problem. Moral truths he argued could not exist because there was no acceptance of any moral meaning. Nonetheless, he argued that even if there was the possibility of a moral meaning, moral truth would still be difficult as in the normal course of events the verification of a truth relies on empirical evidence: But moral truths do not. Moral truths rely on moral intuition and such "intuitions resist proof" (Hill, 1995, p. 589). As a result different people can disagree - as our ICT interviewees sometimes did - on a "moral issue precisely because they have opposing intuitions" (Hill (1995, p. 589) - italics in the original). This, Hill argued, exposes the crux of our problem. The problem is that we live in an age in which there is little consensus. Consequently both "moral meaning and truth are very problematic" (Hill, 1995, p. 590). Following Hill business ethicists might engage in endless discussions about ethics, but regardless of that it is exceedingly difficult "to communicate a moral proposition that can be understood" (1995, p. 590). Contemplating those circumstances Hill speculated as to Socrates being correct in arguing that "morality cannot be taught" (1995, p. 590) unless those studying it approached it with the correct "attitude" (1995, p. 591). How such an attitude might be engendered with regard to Australian ICT professionals does concern us in our paper. If we fail to do so we cannot help them identify ethical problems let alone solve them. That, however, returns us to the discrepancy we discussed earlier: that gap between what is taught and what is experienced. In such circumstances there is very little opportunity for any consensus to emerge.

Hill (1995) is not alone in having such misgivings as to the possibility of teaching business ethics. Phillips and Margolis (1999) also had major reservations as to using ethics to teach business ethics. However, for many the problem is not ethics per se but the actual variant of ethics with rule-based ethics the culprit. As a result Alasdair MacIntyre is promoted by many business ethicists (amongst others see Brewer (1997); Horvath (1995); Moore (2003)) who favour his championing of virtue ethics over utilitarian or deontological theories. That, however, might not be as simple as it sounds. The Australian ICT industry contains diverse bodies with some, as we discuss with regard to our interviewees, having very different priorities to others. Identifying a commonly accepted virtue in such a diverse body might be every bit as difficult as agreeing on Hill's understandable moral proposition. MacIntyre sees virtues as "significantly defined by local social or cultural perspectives" (Arthur \& Carr, 2013, p. 29). But Australian ICT professionals experience cultural differences, as we discuss in the paper, and MacIntyre himself has argued that given such circumstances "there can be no common moral education" (Arthur \& Carr, 2013, p. 29). If that is so teaching business ethics to ICT professionals as it is usually taught by virtue ethicists is increasingly futile. Instead we should be seeking a way to help ICT professionals identify ethical problems despite those circumstances.

Such an argument has conceivably been accepted by our leading educators (Glanzer \& Ream, 2008). Whilst past generations of educators thought the university should provide a moral education this is no longer the case which is why ICT professionals increasingly grapple with this in their workplace (Glanzer \& Ream, 2008). Glanzer and Ream (2008) quote contemporary leading educators as, contrary to the expectation of their predecessors, insisting that when it came to moral questions the faculty left it to the students to find their own answers as the faculty could not provide them. In making that argument they too invoke MacIntyre's observation as to contemporary universities having less agreement than ever regarding "what it means to be fully human" (Glanzer \& Ream, 2008, p. 114). As to why this was not so in the past, they explain in that prior period the existence and acceptance of a "metanarrative (by 
which) we mean a story" (Glanzer \& Ream, 2008, p. 114). That story provided both understanding and guidance and, furthermore, knowledge as to those virtues which should be acquired. Without such an acceptable metanarrative for ICT professionals there can be no general consensus as to any of that. If we are serious about helping ICT professionals identify ethical problems despite their circumstances much of our effort must be in creating for them a suitable metanarrative. In doing so we need to be most cognisant of the dissimilarity between what they are taught as to ethics and those ethical dilemmas ICT professionals actually encounter in their workplaces.

Glanzer and Ream (2008) do not mention Hill (1995) but their arguments endorse his as to moral truths not being reliant on empirical evidence with the result that there is little consensus regarding them. Hence "ethics became marginalised as a field of knowledge" (Glanzer \& Ream, 2008, p. 115). Such circumstances do not however negate morality. On the contrary all they do is stress the necessity of finding "some other basis for moral commonality" (Glanzer \& Ream, 2008, p. 115). That is increasingly necessary for those in the ICT profession. Glanzer and Hill (2013, p. 293) explain how the desire of the universities to provide practical courses led to "ethics largely disappear(ing) from the curriculum". Later it reappeared in the guise of "narrow professional ethics courses" (2013, p. 293) such as computer ethics but for the reasons explained by Hill (1995) and also by Arthur and Carr (2013) such courses cannot readily be taught by means of utilitarian, deontological or virtue ethics as is unfortunately usually the case. For a discussion on why these three fail to do so, the reader is encouraged to read Comer \& Schwartz (2015) careful explanation of the reason for their failure.

Criticisms of utilitarian, deontological and virtue ethics are not a recent development. Ellerman (1998, p. 192) arguing that at times "moral aspiration is absurd" cites approvingly "Nietzsche's suspicion that morality is eminently dangerous" (1998, p. 191). Friedrich Nietzsche (1844-1900) described Kant as "a moral fanatic" (Nietzsche as quoted by Russell (1972, p. 761)) and dismissed Mill as a "blockhead" (Nietzsche as quoted by Russell (1972, p. 762)). But Nietzsche, whilst he might have helped instigate a growing disenchantment with all those philosophies, lived in a time when most accepted them. As such for the vast majority the prevailing metanarrative held. It is the decline of any dominant metanarrative which is our major concern regarding the ability to improve that ethical awareness which ICT professionals require to identify ethical problems.

For an extremely long period whilst everything changed everything, paradoxically, remained much the same. The Christians closed Plato's Academy (Rosenstand, 2006) but nonetheless appropriated much of Greek philosophy for their own purposes (Neusner \& Chilton, 1997). As such despite these changes, or perhaps regardless of them, a dominant story held sway and provided society with a metanarrative it could subscribe to and around which some consensus could be acquired.

Brown (1994, p. 37) has argued that our search for "objective knowledge, universal laws and absolute truths was a myth, legitimized by a high-level story-line, or metanarrative". Most significantly this metanarrative could vary but what was essential was that it be accepted. However, according to Brown (1994, p. 37) this "potency of metanarratives has declined": indeed, he disputes that there is any longer the acceptance of a metanarrative. That has dire implications for the teaching of morality to ICT professionals for the very reasons which Hill (1995) and Arthur and Carr (2013) explained. Without the widespread acceptance of a metanarrative any ethical discussions are bound to be meaningless as there can be no underlying acceptance of any moral propositions. This is the fate of ethics subjects being taught in ICT courses. And yet, whilst it is, that gap between what is taught in such subjects and the reality of ethical dilemmas experienced by ICT professionals employed in the workplace provides the opportunity to create anew for such subjects a valid metanarrative: one that is firmly grounded in the ethical reality experienced by ICT professionals. What is therefore essential is a study which highlights those ethical challenges that ICT professionals experience in their workplaces. Such ethical challenges are not going to be encountered by ICT students while they are at university. Until they experience the reality of their future workplaces this will merely be a story. But it is essential for that story to become the dominant story and in 
doing so to provide a valid metanarrative. Without it regarding ethics nothing "meaningful" (Hill, 1995, p. 585) could ever be discussed by them: And seeking to educate ICT students as to the ethical dilemmas they will face in the workplace will be a largely hopeless endeavour.

There is a long acknowledged link between the professions and ethical conduct. Professionals have specific privileges and "as a corresponding item of such privileges, professionals are subject to restrictive ethical duties" (Mullerat, 2013, p. 180). High profile failures of professionalism in business obfuscate an underlying change in society toward greater ethical behaviour in the workplace. Cases like Enron in the USA, phone tapping of celebrities and politicians by newspaper journalists in the UK, and more recently the 2014 systemic fraud amongst Commonwealth Bank financial advisors in Australia, are magnets for the media and suggest that unprofessional behaviour continues unabated in society.

The main contribution of this article is it highlights the inadequacy of what is taught to ICT graduates prior to entering the workplace revealing the changes that need to take place in tertiary education, to better prepare ICT graduates. Having introduced ICT professional ethics within the wider context of professionalism, this article next reviews prior work relevant to qualifications and ethics education. It then describes the mixed methods approach of the present study, which involved a quantitative survey of 2,315 Australian ICT professionals and qualitative interviews with 43 of them. The findings are discussed alongside each approach separately.

\section{Qualifications and ethics education}

Most ICT professionals work in organizations. Far too often such organizations do not foster the morality of those within the organization but frustrate any such behaviour. Comer and Vega (2011) have argued that is so as within the organization employees face two different types of consequences. The one set of consequences are those that affect an employee personally. The other is when there are consequences not for that employee, but for others. Comer and Vega do not dispute that individuals are moral. But they argue that they will most probably discard their morality in two situations.

The first situation is when the organization imposes situational pressures upon the employees so that if they heed their own morality they will incur major personal costs. As Comer and Vega explain "we all have a breaking point at which we jettison our morals" (2011, p. 28 - italics in the original). Extreme situational pressures within the organization can easily push employees over that breaking point.

The second situation is where "the moral intensity of the circumstances is relatively low" (Comer and Vega, 2011, p. 26 - italics in the original). This is those situations where should an employee breach their own morality the consequences for others will be minimal. Again, Comer and Vega argue that in such circumstances employees will easily abandon their morality. Conversely where the moral intensity is relatively high they will not readily do so. In support of their arguments Comer and Vega provide the case of an IT specialist in a hospital who refuses "to change a patient's computerised records" (2011, p. 28) although this IT specialist had been dishonest earlier about things which she thought were of very minor consequence for others.

Comer and Vega thus present two situations an employee will face. The first has to do entirely with the employee. Heightened situational pressures affect only the wellbeing of that employee. But the second situation depends on the employee's "perceptions of its collective importance" (2011, p. 28). They argue that this latter aspect impacts directly upon the former as employees "are more likely to do the right thing, even at personal expense, to the extent that (their) behaviour affects others" (2011, p. 29). But they caution that employees can overtime avoid doing what is morally right. They can do so by reducing dissonance by lowering their moral standards or by "reinterpreting the issue as less morally intense" (Comer and Vega, 2011, p. 31). Furthermore, they can become "desensitized to the intensity of moral encounters" (Comer and Vega, 2011, p.31) by continuing to engage in immoral acts "of incrementally greater 
intensity" (Comer and Vega, 2011, p. 31). Earlier we mentioned Enron. For Comer and Vega Enron is an example of a process of increasing desensitization where Enron employees "grow accustomed to acting in ways (they) once thought (they) never would or could" (2011, p. 31). For those very reasons how students are educated as to their moral behaviour before entering the workplace is crucial.

ICT professionals were once students and regarding that there is evidence that a mismatch exists between the way in which tertiary students are prepared for the workplace challenges and the types of situations they subsequently experience (Al-Saggaf, Burmeister, \& Weckert, 2015). As Comer and Vega (2011) argue their perceived moral intensity of such situations has ramifications for those involved. And their perceptions of that moral intensity will be influenced by the type of moral education they had. Although there have been many attempts to improve ICT ethics education (Al-Saggaf \& Burmeister, 2012; Fleischmann, 2010; Simpson, Nevile, \& Burmeister, 2003), it appears that it has only had limited effect. A study of the perceptions of recent graduates, who had been working for at least 18 months, revealed that despite their course having a dedicated final year ethics subject, nothing they had studied had prepared them for the types of ethical dilemmas that they faced in their employment (Burmeister \& Sharma, 2005). According to Comer and Vega whilst they might have been taught about ethics they had not been taught how in those circumstances "to become less vulnerable to organizational factors, and to act in concert with (their) moral values" (2011, p. 34 ) which they need to do if they are "to take ownership of (their) ethical choices" (2011, p. 34). An industry survey in 2006 involving 351 ICT professionals, 30 of whom were then interviewed, found that the ethics components of ICT courses had minimal effect on the professional behaviour of ICT practitioners (Lucas \& Weckert, 2008). The literature, of which there is relatively little on the specific topic of efficacy in ICT (Buchko \& Buchko, 2009) and in wider business education (Hun-Joon, 1998), generally supports this. There is some evidence too that formal qualifications in ICT do not have a positive effect ethically. Lucas and Weckert (2008) found that those practitioners with ICT qualifications were more likely to do what they were asked to do, even if they considered it ethically dubious. One possible reason for this is that ICT education may be very narrow. Perhaps there is a technical emphasis in ICT qualifications that reflects a lack of a professional attitude. Lucas and Weckert (2008) did not distinguish between university, TAFE or other qualifications. Despite the fact that many (though not all) of those interviewed for that project expressed strong support for ethics education, the 2006 survey suggested that ethics education as part of an ICT course appeared to have little positive effect on the ethical decision making or ethical behaviour of those working in the industry.

One explanation for this is that a significant difference exists between the content of typical ethics courses and what practitioners see as the main ethical problems. A survey of the material covered in university courses showed an intersecting but substantially different set of issues (Lucas \& Mason, 2008). The common topics covered were the standard ones of privacy, security, cybercrime, intellectual property, regulating commerce and free speech and a few others, with professional ethics being one topic but frequently left unspecified. A weakness of that research was that it was based on online descriptions of courses and contents of commonly used textbooks. The main ethical concerns of practitioners as expressed in surveys differed from the typical content of accredited university courses as found in a Web examination of those courses and the contents of the most common texts used (Lucas \& Mason, 2008).

The 2006 survey of practitioners ranked privacy and intellectual property issues prominently but what could generally be described as professional issues, that is, issues where practitioners must make work-related decisions, dominated. High on the list were compromising quality to meet deadlines, unprofessional behaviour, making false promises and conflicts of interest. Also significant were compromising functionality and requirements to meet deadlines. Unprofessional behaviour also figured large in the extra comments section. Typical concerns were blaming others for one's own mistakes, poor team contributions, awarding contracts without due process, overpricing and under quoting of time, and overstating of skills. The issue of professionalism was also of major concern in the interviews and most of the same worries 
surfaced. A number of related new ones were also mentioned; of particular significance were responsibility and informed consent.

Building on Lucas and Weckert (2008) and Lucas and Mason (2008) 2006 survey, Al-Saggaf et al. (2015) conducted another survey in 2013 in which they asked Australian ICT professionals about the most common ethical problems that they faced in their workplaces and what are the most effective strategies for solving them. Unlike the 2006 survey which had only 351 responses, and for which responses were gathered over a six month period, from July 10, 2006 to January 31,2007 , the 2013 survey involved 2,315 ICT professionals and was only open for 2 months, from 12/9/2013 to 6/11/2013. That is, the 2013 result of $12.4 \%$ responses from professional members of the Australian Computer Society (ACS) compared to a 1.9\% response rate in 2006, and over a significantly shorter time frame, suggests that there is much greater awareness and interest in the ICT society about professionalism and ethics, now, compared to seven years ago.

However, what has not changed is the type of ethical challenges faced in the ICT workplace. Indeed, the top ten problems across the seven year period were virtually identical (Table 2 below provides more information). This raises the question: is it possible that seven years on that ethics education as part of ICT courses continued to have little positive effect on the ethical decision making or ethical behaviour of those working in the industry?

This article investigates using data from this 2013 survey, which ethical problems are actually experienced in the ICT workplace, so that educators can be better informed about what needs to be taught to future ICT students. The 2006 survey did not distinguish between university, TAFE or other qualifications. The 2013 survey allowed participants to select their qualifications from a list of 10 options. The article then addresses the following questions: Do information and communications technology (ICT) professionals who have ICT qualifications believe that the ethics education they received as part of their ICT degrees helped them recognise ethical problems in the workplace and address them? If they do, are they also influenced by their personal ethics? What else helps them recognise ethical problems in the workplace and address them? And what are their views in relation to the impact of ethics education on professionalism in the ICT workplace?

\section{Methodology and Findings}

\subsection{The quantitative survey}

A mixed methods approach has been adopted for the project. Three phases were involved, the first two of which are addressed herein. The first phase involved a quantitative survey of members of the ACS, administered using SurveyMonkey.com, to allow the participants to fill the questionnaire and return it over the internet. The survey was informed by the results of a 2006 survey conducted by Lucas and Mason (2008) and also by the instrument they used. All ACS members were invited to participate in the web-based survey by direct email sent to them by the ACS once on 12 September 2013, and the survey was closed on 6 November. The online questionnaire was prefaced by the ethics consent statement and a description of the study. The questions comprised both closed and open ended questions. This article reports only on the closed ended questions.

\subsubsection{Sample (quantitative survey)}

A total of 2,315 participants completed the questionnaire. The average number of years of experience for all respondents was 19 years. Table 1 shows a summary of the demographic information of all participants. It should be noted that with the exception of the Qualifications variable, the independent variable in this study, for which all groups are shown and all percentages add up to 100, not all percentages add up to 100 in the case of the other variables as respondents' choices with smaller percentages are not shown. 


\begin{tabular}{|c|c|c|}
\hline \multicolumn{2}{|c|}{ Demographic information } & \multirow{2}{*}{$\begin{array}{l}\text { Participants } \\
84.5 \%(\mathrm{~N}=1940)\end{array}$} \\
\hline Gender & Male & \\
\hline & Female & $15.5 \%(\mathrm{~N}=356)$ \\
\hline \multirow[t]{4}{*}{ Age } & 31 and 35 years & $11 \%(\mathrm{~N}=254)$ \\
\hline & 41 and 45 years & $12.4 \%(\mathrm{~N}=287)$ \\
\hline & 51 and 55 years & $14.1 \%(\mathrm{~N}=325)$ \\
\hline & 61 years and above & $12.2 \%(\mathrm{~N}=282)$ \\
\hline \multirow[t]{6}{*}{ State } & ACT & $10 \%(\mathrm{~N}=247)$ \\
\hline & NSW & $30.4 \%(\mathrm{~N}=696)$ \\
\hline & QLD & $12.2 \%(\mathrm{~N}=279)$ \\
\hline & SA & $5.5 \%(\mathrm{~N}=120)$ \\
\hline & VIC & $25.4 \%(\mathrm{~N}=581)$ \\
\hline & WA & $9.5 \%(\mathrm{~N}=218)$ \\
\hline \multirow[t]{4}{*}{ Occupational Category } & Managers & $33.8 \%(\mathrm{~N}=698)$ \\
\hline & Developers & $14.8 \%(\mathrm{~N}=307)$ \\
\hline & Consultants & $24.3 \%(\mathrm{~N}=5 \mathrm{O} 2)$ \\
\hline & Technical Support & $13.3 \%(\mathrm{~N}=277)$ \\
\hline \multirow[t]{2}{*}{ Geographical Location } & Capital City Or Metropolitan & $90.6 \%(\mathrm{~N}=2069)$ \\
\hline & Regional Areas & $9.4 \%(\mathrm{~N}=215)$ \\
\hline \multirow[t]{4}{*}{ Industry Type } & Education & $12.3 \%(\mathrm{~N}=244)$ \\
\hline & Finance & $11.9 \%(\mathrm{~N}=235)$ \\
\hline & Government & $15.4 \%(\mathrm{~N}=304)$ \\
\hline & ICT & $34.2 \%(\mathrm{~N}=676)$ \\
\hline \multirow[t]{2}{*}{ Industry Sector } & Private Sector & $57.4 \%(\mathrm{~N}=1,282)$ \\
\hline & Public Sector & $27.5 \%(\mathrm{~N}=614)$ \\
\hline \multirow[t]{3}{*}{ Job Classification } & Permanent Full-Time Employees & $65.4 \%(\mathrm{~N}=1,388)$ \\
\hline & Independent Consultants & $5.2 \%(\mathrm{~N}=110)$ \\
\hline & Self-Employed & $5 \cdot 3 \%(\mathrm{~N}=112)$ \\
\hline \multirow[t]{10}{*}{ Qualifications } & Non-ICT degree or diploma & $5.2 \%(\mathrm{~N}=114)$ \\
\hline & Experience & $3.9 \%(\mathrm{~N}=85)$ \\
\hline & Industry or Profession Certification & $6 \%(\mathrm{~N}=132)$ \\
\hline & Diploma & $8.3 \%(\mathrm{~N}=181)$ \\
\hline & Degree & $36.4 \%(\mathrm{~N}=794)$ \\
\hline & Certificate & $2.7 \%(\mathrm{~N}=58)$ \\
\hline & Self-educated & $0.8 \%(\mathrm{~N}=17)$ \\
\hline & Trade qualification & $0.5 \%(\mathrm{~N}=10)$ \\
\hline & Higher Degree & $34.6 \%(\mathrm{~N}=756)$ \\
\hline & No qualifications & $1.6 \%(\mathrm{~N}=35)$ \\
\hline
\end{tabular}

Table 1: A summary of the demographic information of all participants

\subsubsection{Statistical analysis}

The 2013 survey asked participants to address a total of 57 problems, which extended the 2006 survey of 16 problems. The additional categories in the 2013 survey were based on the additional comments in the 'Other' section of the open-ended questions in the 2006 survey (Lucas \& Mason, 2008; Lucas \& Weckert, 2008). Table 2 lists the top 10 ethical problems along with the number of responses and their percentages. 


\begin{tabular}{lcc}
\hline \multicolumn{1}{c}{ Ethical problem } & $\begin{array}{c}\text { Number of } \\
\text { responses }\end{array}$ & $\begin{array}{c}\text { Percent } \\
\text { of Cases }\end{array}$ \\
\hline Compromising quality to meet deadlines & 1104 & 47.7 \\
Blaming others for own mistakes & 957 & 41.4 \\
Compromising functionality to meet deadlines & 846 & 36.6 \\
Overworking staff & 762 & 32.9 \\
Incompetence & 750 & 32.4 \\
Conflict of interest & 682 & 29.5 \\
Unprofessional Behaviour & 633 & 27.4 \\
Compromising user requirements to meet deadlines & 632 & 27.3 \\
Bullying & 630 & 27.2 \\
Compromising security to meet deadlines or make things work & 611 & 26.4 \\
\hline
\end{tabular}

\section{Table 2: The top 10 ethical problems}

When asked to indicate their feeling towards the statement "My ethics education or training help me in identifying the ethical problems and solving them" $66.1 \%(\mathrm{~N}=1268)$ of the participants in the survey indicated that they agree or strongly agree with this statement and only $6.1 \%(\mathrm{~N}=117)$ disagree or strongly disagree with this statement. This suggests that the majority of the survey participants thought that ethics education is helpful for recognising ethical problems and addressing them.

We wanted to determine if there were significant differences in agreement with the statement "My ethics education or training help me in identifying the ethical problems and solving them" among the participants who reported having various levels of qualifications. The qualifications variable was the independent variable and the statement about ethics education or training was the dependent variable. The independent variable was of type categorical comprising 10 levels ranging from 'no qualifications' to 'higher degree' but including a nonICT degree or diploma; while agreement with the statement, the dependent variable, was assessed using a five-point Likert scale ranging from Strongly Agree to Strongly Disagree. It should be noted that it is possible the participants in this study understood ethics education to a larger extent in terms of the curriculum and to a less extent in terms of the pedagogy and the roles of both the student and teacher in the learning process.

Given the independent variable is categorical and the dependent variable is assessed using a Likert scale, an analysis of variance using a one-way between groups ANOVA would have been the most appropriate test, especially that the homogeneity of variances assumption was tested and verified. However since the dependent variable is significantly positively skewed (i.e. did not display a normal distribution), this statistical tool was judged not to be suitable for the analysis; therefore we used Kruskal Wallis, the corresponding procedure for non-parametric dependent variable, to test the differences in agreement with this statement among the participants.

Prior to conducting the Kruskal Wallis, the assumption of homogeneity of variances for nonparametric tests was verified by: first, ranking the values of all the dependent variable responses; second, computing the ranks means; and then obtaining the absolute difference between the ranks and the ranks means (i.e. the two newly created variables). Finally, an analysis of variance was performed on these absolute difference scores (in the context of this analysis, this procedure is called a non-parametric Levene test). Since Levene's P value was not significant, $F(9,1858)=1.01, p=.425$, the assumption of homogeneity of variances was satisfied.

\subsubsection{Findings (quantitative survey)}

A significant difference in agreement with the statement was found among the participants who reported having different levels of qualifications, $\chi^{2}(9, N=1868)=22.004, p=.009, \eta p 2$ $=.0118$. That said, since only $1.18 \%$ of the variance in agreement with the statement was accounted for by the qualifications variable, the effect of this variable is very small. 
The mean ranks indicated that those with Non-ICT degree or diploma had the highest ranks (Mean Rank= 1116.07), with those with an ICT degree ranked fifth form the top (Mean Rank= 944.87); while those without any qualifications were ranked tenth (lowest) (Mean Rank = 839.58). See Table 3 for the Mean Ranks of all the qualification groups.

\begin{tabular}{lcc}
\hline \multicolumn{1}{c}{ Please indicate your highest ICT qualifications. } & $\mathrm{N}$ & Mean Rank \\
\hline Non-ICT degree or diploma & 99 & 1116.07 \\
Experience & 68 & 1009.31 \\
Industry or Profession Certification & 113 & 955.02 \\
Diploma & 152 & 955.01 \\
Degree & 685 & 944.87 \\
Certificate & 47 & 941.89 \\
Self-educated & 14 & 897.04 \\
Trade qualification & 8 & 885.69 \\
Higher Degree & 656 & 884.86 \\
No qualifications & 26 & 839.58 \\
Total & 1868 & \\
\hline
\end{tabular}

Table 3: The Mean Ranks of all the qualification groups

In order to evaluate if the groups with the highest Mean Ranks are statistically different from those with lowest Mean Ranks, the statistically significant Kruskal Wallis was followed-up with Kruskal Wallis pairwise analysis, while selecting only the cases (pairs) of interest. A MannWhitney would have been the preferred test for this situation, but since it does not show eta square it was not selected.

A significant difference in agreement with the statement about ethics education was found between the participants who reported having Non-ICT degree or diploma and those who reported having no qualifications, $\chi^{2}(1, N=125)=5.325, p=.021, \eta_{p}{ }^{2}=.0429$. Similarly, a significant difference in agreement with the statement was found between the participants who reported having Non-ICT degree or diploma and an ICT degree, $\chi^{2}(1, \mathrm{~N}=784)=9.837, \mathrm{p}=$ $.002, \eta_{\mathrm{p}}{ }^{2}=.0125$. This suggests that those with Non-ICT degree may have benefited more from their degree in terms of raising their ethics awareness than those with an ICT degree or those who reported having no qualifications. It is not clear why this is the case but it could be because non-ICT students have more exposure to the humanities than otherwise which allows them to engage with the ethics curriculum better than students who have only been exposed to technical-related curriculum. Further research is needed to shed light on this unexpected finding.

Also a significant difference in agreement with the statement was found between the participants who reported having a Non-ICT degree or diploma and those who reported having an Industry or Professional Certification, $\chi^{2}(1, N=212)=5.073, p=.024, \eta_{p}{ }^{2}=0.24$. Further research into the varieties of ICT degrees and diplomas is required to discover which ones are more helpful in recognising ethical problems and addressing them than an Industry or Profession Certification, in order to help all educators better understand how to prepare ICT graduates for the workplace.

But a significant difference in agreement with the statement was found between the participants who reported having an ICT degree and those having a higher degree, $\chi^{2}(1, N=$ 1341) $=4.730, p=.030, \eta_{p}{ }^{2}=003$, suggesting an ICT degree could be more effective in this regard than a higher ICT degree. Again, further research into the varieties of ICT degrees and diplomas is required to discover which ones are more helpful. Interestingly, there is no significant difference in agreement with the statement between the participants who reported having an ICT degree and those who reported not having any qualifications, $\chi^{2}(1, N=711)=$ $1.096, p=.295$; and no significant difference in agreement with the statement was found 
between the participants who reported having an ICT degree and those who reported having an Industry or Profession Certification, $\chi^{2}(1, N=798)=.041, p=.840$. This again hints at the inadequacy of the ICT courses in developing ethics awareness among graduands. Table 4 summarises these findings.

\begin{tabular}{llc}
\hline & Qualifications & A significant difference \\
\hline Non-ICT degree or diploma* $^{*}$ & No qualifications & Yes \\
Non-ICT degree or diploma* $^{*}$ & ICT degree & Yes \\
Non-ICT degree or diploma* & Industry or Profession Certification & Yes \\
ICT degree* & Higher ICT degree & Yes \\
ICT degree & No qualifications & No \\
ICT degree & Industry or Profession Certification & No \\
\hline * & &
\end{tabular}

* More helpful

Table 4: Summary of findings relating to agreement with ethics education or training

Of particular interest to this study is the statement "My personal ethics helps me in identifying the ethical problems and solving them" (see Table 5 for the list of the nine statements assessed in the survey). The reason for this interest is because if those with qualifications believed that their personal ethics was sufficient in identifying the ethical problems and solving them, it may mean that their ethics education made little difference to their professional lives. To investigate whether or not there is a difference in agreement with this statement among the participants with various qualification levels, a Kruskal Wallis analysis was employed. Prior to running the Kruskal Wallis tests, the assumption of homogeneity of variances was verified and tested using the non-parametric Levene test.

The analysis revealed that there is no significant difference in agreement with the statement among the participants, $\chi^{2}(9, \mathrm{~N}=1879)=9.995, \mathrm{p}=.351$. This indicates that qualifications did not account for any variance in agreement with the statement about personal ethics suggesting personal ethics did not influence participants with qualifications as ethics education did. This suggests that those with qualifications did not believe that their personal ethics was sufficient in identifying the ethical problems and solving them.

To investigate if the difference in agreement with ethics education or training that was found among the participants who reported having various levels of qualifications is not unique to this dependent variable, additional Kruskal Wallis analyses were performed on the remaining seven statements. Prior to running the Kruskal Wallis tests, the assumption of homogeneity of variances was verified and tested using the non-parametric Levene test.

The series of Kruskal Wallis analyses found no significant difference in agreement with the remaining statements among the participants who reported having different levels of qualifications. This indicates that other than ethics education, qualifications did not account for any variance in agreement within the remaining statements. This suggests that only ethics education was found helpful for recognising ethical problems and addressing them among the participants who reported having qualifications. But it was non-ICT qualifications that made the bigger difference; not the ICT qualifications. 


\begin{tabular}{ll}
\hline$\#$ & \multicolumn{1}{c}{ Statement } \\
\hline 1 & The Code of Ethics of my professional body, such as the ACS and SAGE, helps me in identifying \\
& the ethical problems and solving them. \\
2 & My personal ethics help me in identifying the ethical problems and solving them. \\
3 & My company policies help me in identifying the ethical problems and solving them. \\
4 & My company's culture helps me in identifying the ethical problems and solving them. \\
5 & $\begin{array}{l}\text { My company's ethics committee helps me in identifying the ethical problems and solving them. } \\
6\end{array}$ \\
& $\begin{array}{l}\text { My company's mission/ value statement helps me in identifying the ethical problems and solving } \\
\text { them. }\end{array}$ \\
7 & My ethics education or training help me in identifying the ethical problems and solving them. \\
8 & My industry licences or certification help me in identifying the ethical problems and solving them. \\
9 & $\begin{array}{l}\text { The industry standard I am adopting, such as CoBIT and ITIL, helps me in identifying the ethical } \\
\text { problems and solving them. }\end{array}$ \\
\hline
\end{tabular}

Table 5 The nine statements assessed in the survey

\subsection{The qualitative interviews}

The second phase of the study involved a set of semi-structured, in-depth interviews with 43 participants selected from those who responded to the first phase. The interviews were conducted during the month of February 2014 and took place in six Australian capital cities. The purpose of these follow-up interviews was to discover participants' perceptions in regards to the nature of the ethical challenges experienced in the ICT workplace and how exactly these problems are often solved. Purposive sampling was adopted to select the participants from those who had indicated a willingness to be interviewed. Purposive sampling allowed the researchers to choose cases that were representative of all sub-groups and personal characteristics which might be of interest to the study (Patton, 2002). The sample drawn included professionals from a range of ICT organisations, both large and small, government and private sector, representing different geographic locations, ages, gender, types of jobs, and employment experience. All the interviews were tape recorded and transcribed verbatim.

The transcribed interviews were analysed using thematic analyses. Data analysis was completed using QSR NVivo 10. While the first author completed the data analysis, the second author reviewed the outcome of this analysis. This was to address bias that may arise from the involvement of a single researcher. Free nodes, those nodes not organised or grouped, were created based on keywords in the interview documents. Similar text within the interview documents was located and assigned to these nodes. These nodes then acted as 'buckets' in the sense that they held all the data related to a specific node. At the end of the creation of the free nodes theses free nodes were further divided into tree nodes. That is, broader categories were developed to group the free nodes. This was to create a hierarchy that made it easy to make sense of the data and facilitate interpretation.

\subsubsection{Findings (qualitative interviews)}

When asked during the semi-structured interviews for their views about effective strategies for dealing with unprofessional behaviour, 22 interviewees out of 43 suggested ethics education or incorporating ethics in the IT courses. The following comments typify these semi-structured interview participants' views: "So going back to say the ACS and the Universities, there ought to be an ethics segment in education" (43, Consultant, Sydney); "Maybe the only thing that will, is better education that might stop people from doing ..." (69, Professional Salesman, Sydney); "Ethics being taught as part of IT courses ... some ethics component in every course and not just done as a - oh and by the way here's this ..." (49, Public Servant, Canberra); "It's education and training in ethics at schools and universities" (48, Company Director, Sydney); "There will always need to be an education component because ethics is not something we're really touching in our, in the higher education" (32, Software Tester, Canberra); "We're always checking to see that the Universities actually teach ICT ethics in some way that's acceptable, that's reasonable" (50, Course Accreditation Advisor, Canberra); "If the Uni had had this e-Learning thing from the ACS or whomever and included it in one or more of the finishing units, I think it would've been really good" (24, Business Analyst, Sydney); "At the 
bottom level I would say that ethics and humanities need to be included in our courseware" (54, Consultant, Perth).

The findings from the interviews are consistent with the findings from the survey in two ways: first, that ethics education is crucial for enabling ICT professionals to recognise ethical problems and resolve them. Second, that educators need to consider how to better prepare ICT graduates for the types of moral dilemmas that they are likely going to face in the workforce. The following quotation from Interviewee 29 (48, Company Director, Sydney) hints to this mismatch:

You know when you do your IT degree the technology that they teach you at the beginning is redundant by the time you finish your degree. What you learn is the soft skills, the professional skills, how to write quality code, how to apply technology to business, how to do analysis, how to do design, how to architect. Those principles don't change yeah? The technology you use is redundant by the time you finish your degree but degrees are structured around teaching technology and all these things come secondary; no, it's the other way around.

Interviewee 29 (48, Company Director, Sydney) also adds:

Jobs that are going to be created in three years' time don't exist in now - App developers didn't exist four years ago - I mean there was like 10 guys on the planet did it; now there's thousands of them. They - yeah okay they need a little bit of Applecoding language skills, that sort of thing. But what they need is they need the ability to recognise a problem ... so doing courses that do teach you ethics, but teach you generic capacities and capabilities that you can transfer into multiple areas of society is what's needed and a lot of the courses aren't structured that way.

Indeed, given the pace at which technology advances, it is not unusual for a particular technology to be obsolete by the time a student completes a course. Thus it is important, as this Interviewee argues, that IT courses prepare students adequately for the unknown and uncertain future and also teach them to be ethical.

The problem is that some university academics are not serious about ethics education or that they pay lip service to this area. Interviewee 24 (43, IT Manager, Melbourne), for example, said "my IT course granted long time ago right - didn't teach me much at all about ethics and it really didn't". Interviewee 25 (31, IT Manager, Melbourne) concurs adding that "when I did my degree years ago, I don't recall there being anything in the degree about ethics in the IT world". Interviewee 41 (50, Course Accreditation, Canberra) provides evidence of this careless attitude towards ethics in IT courses:

It depends on how they do it - if they do it in the unit outline and it's against the ACS ... then you can probably pick it up. But quite often they do it separately from that, and they claim all this stuff. You go back and look at the unit and there's not a trace of it. And so, they're pretty cheeky. ... they just don't know what's going on, or they gave it to someone who doesn't care or ...

According to Interviewee 41 one reason for this problem is that there is no one qualified to teach IT ethics:

I think one of the problems is that the teaching of ethics in ICT courses - well, there's no one there qualified to do it - or it's very unusual, that is, because if you do an ICT degree ... hardly say that when you graduated you are now qualified to teach ethics. And when you've finished your PhD you're no better qualified ... to do it - to teach it.

The exemplary quotations above provide further empirical evidence for the inadequacy of the current ICT courses in preparing the ICT graduates prior to entering the workplace. From this evidence it is clear that changes need to take place in tertiary education, to better prepare ICT graduates. 


\section{Conclusion}

Findings from both, the survey and the interviews, found ethics education to be the way forward if ICT professionals are to recognise ethical problems in the workplace and solve them. But the findings also suggested that educators need to consider how to better prepare ICT graduates for the workplace challenges and the types of situations they subsequently experience. Further work is needed to explore how tertiary educators can develop ICT courses that better prepare graduates for the kind of challenges they will confront in the workplace.

Lucas and Weckert (2008) and Lucas and Mason (2008) found that there is a mismatch between what is taught and what is experienced in the workplace and that ethics education only marginally assisted ICT employees with making ethical decisions. They also found that those with formal ethics education were only slightly less likely to rely on their personal ethics when making ethical decisions in the workplace. Our findings are consistent with their findings regarding ICT courses making little difference to the ICT employees' professional development and that ethics education only marginally assisted ICT employees with making ethical decisions. But our findings contradict theirs regarding personal ethics. Personal ethics was not invoked by those who reported having various levels of qualifications and ethics education was found to be helpful in identifying ethical challenges and addressing them. Further research could shed light on the effect of qualification on the adoption of ethics education for institutions. Similarly, the implication for tertiary educators also extend to reconsideration of graduate attributes. Further work is needed to highlight which aspects of professionalism should be embedded in ICT courses.

Lucas and Weckert (2008) and Lucas and Mason (2008) have shown that there is mismatch between what is taught and what is experienced by ICT professionals. This study has highlighted the real ethical challenges that face ICT professionals in the ICT workplace. Therefore the work of the present study to reveal the common challenges and strategies for solving them is an important contribution to the literature, because it informs educators about the types of situations for which they need to prepare their students. Given that 2,315 survey respondents provided input about these challenges, making this study the largest of its kind in Australia, educators may want to consult the findings of this study when updating the contents of their textbooks and educational materials. In a rapidly changing environment textbooks and educational materials should be robust.

The $12.4 \%$ survey response rate for the present study contrasts significantly with the $1.9 \%$ achieved in 2006, showing that over the intervening seven years there has been a significant shift within the ICT society towards greater professionalism and ethical behaviour. That shift is part of a wider shift taking place in business, see Ferrero and Sison (2014), and reflects that society as a whole, not just in Australia, but around the world is more concerned nowadays with issues around public trust, reliability of consumer products and service quality. However, that shift has to date not been reflected in the education of students preparing to enter the workforce, but this may be changing as discussed by May, Luth and Schwoerer (2014).

\section{Acknowledgments}

The research reported here is supported by an Australian Research Council Linkage grant (LP130100808), for which the industry partner is the Australian Computer Society. Other team investigators were Professor John Weckert and Mr John Ridge.

\section{References}

Al-Saggaf, Y., \& Burmeister, O. K. (2012). Improving skill development: an exploratory study comparing a philosophical and an applied ethical analysis technique. Computer Science Education, 22(3), 1-19.

Al-Saggaf, Y., Burmeister, O. K., \& Weckert, J. (2015). Reasons behind unethical behaviour in the Australian ICT workplace: An empirical investigation. Journal of Information, Communication \& Ethics in Society, 13(3/4), 235-255. 
Arthur, J., \& Carr, D. (2013). Character in learning for life: a virtue-ethical rationale for recent research on moral and values education. Journal of Beliefs \& Values, 34(1), 26-35. doi: 10.1080/13617672.2013.759343

Berleur, J., Duquenoy, P., Holvast, J., Jones, M., Kimppa, K., Sizer, R., \& Whitehouse, D. (2004). Criteria and Procedures for Developing Codes of Ethics or of Conduct (To Promote Discussion Inside the IFIP National Societies), On behalf of IFIP-SIG9.2.2. Laxenburg, Austria.

Bernoth, M., Dietsch, E., Burmeister, O. K., \& Schwartz, M. (2014). Information Management in Aged Care: Cases of Confidentiality and Elder Abuse. Journal of Business Ethics, 122, 453-460. doi: 10.1007/s10551-013-1770-7

Bowern, M., Burmeister, O. K., Gotterbarn, D., \& Weckert, J. (2006). ICT Integrity: Bringing the ACS Code of Ethics up to date. Australasian Journal of Information Systems, 13(2), 168-181.

Brewer, K. B. (1997). Management as a Practice: A Response to Alasdair MacIntyre. Journal of Business Ethics, 16(8), 825-833. doi: 10.1023/A:1017997200200

Brown, S. (1994). Marketing as Multiplex: Screening Postmodernism. European Journal of Marketing, 28(8/9), 27-51. doi: doi:10.1108/03090569410067631

Buchko, A. A., \& Buchko, K. J. (2009). So We Teach Business Ethics-Do They Learn? Journal of Business Ethics Education, 6, 119-146.

Bull, C. M., \& McLean, R. (2007). Computer and information ethics: the neglect of moral issues associated with e-commerce.

Burmeister, O. K. (2000). Applying the ACS code of ethics. Journal of Research and Practice in Information Technology, 32(2), 107-120.

Burmeister, O. K. (2010). Websites for seniors: Cognitive accessibility. International Journal of Emerging Technologies and Society, 8(2), 99-113.

Burmeister, O. K. (2012). What seniors value about online community. Journal of Community Informatics, 8(1).

Burmeister, O. K., \& Sharma, A. (2005). Professionalism in ICT: meeting the challenge of ethical dilemmas in the workplace. Paper presented at the Fourth Australian Institute of Computer Ethics Conference, Deakin University, Geelong.

Comer D. R. \& Schwartz, M. (2015) Highlighting Moral Courage in the Business Ethics Course. Journal of Business Ethics, DOI: 10.1007/s10551-015-2919-3

Comer, D.R. and Vega, G. (2011). Moral courage in organizations: Doing the right thing at work. M.E. Sharpe, Inc., Armonk, NY.

Dodig-Crnkovic, G., \& Horniak, V. (2005). Good to Have Someone Watching Us from a Distance? Privacy vs. Security at the Workplace. Paper presented at the Proceedings of the Sixth International Conference of Computer Ethics: Philosophical Enquiry, CEPE 200, July 17-19, 2005, University of Twente, Enschede, The Netherlands Conference retrieved from

Drucker, P. F. (1981). What is 'business ethics'? The Public Interest, 63, 18-36.

Ellerman, C. P. (1998). A Talent for Life. The Journal of Value Inquiry, 32(2), 191-204. doi: 10.1023/A:1004269911054

Fawkes, J. (2014). Trust Me, I'm a Professional Public Relations Ethics and Professionalism: the shadow of excellence (pp. 51-76). London \& New York: Routledge.

Ferrero, I., \& Sison, A. J. G. (2014). A quantitative analysis of authors, schools and themes in virtue ethics articles in business ethics and management journals (1980-2011). Business Ethics: A European Review, 23(4), 375-400. doi: 10.1111/beer.12057 
Fleischmann, K. R. (2010). Preaching What We Practice: Teaching Ethical Decision-Making to Computer Security Professionals. Lecture Notes in Computer Science, 6054, 197-202.

Glanzer, P. L., \& Hill, J. P. (2013). Why most American universities have given up on human purpose and meaning: a Critical exploration of the historical story. Journal of Beliefs \& Values, 34(3), 289-299. doi: 10.1080/13617672.2013.828951

Glanzer, P. L., \& Ream, T. C. (2008). Addressing the moral quandary of contemporary universities: rejecting a less than human moral education. Journal of Beliefs \& Values, 29(2), 113-123. doi: 10.1080/13617670802289494

Gotterbarn, D., \& Miller, K. (2009). The public is the priority: making decisions using the Software Engineering Code of Ethics. IEEE Computer, 42(6), 66-73.

Hedström, K. (2007). The values of IT in elderly care. Information Technology and People, $20(1)$.

Hill, J. (1995). Can We Talk About Ethics Anymore? Journal of Business Ethics, 14(8), 585592.

Horvath, C. M. (1995). Excellence v. effectiveness: Macintyre's critique of business. Business Ethics Quarterly, 5(3), 499-532.

Hun-Joon, P. (1998). Can Business Ethics Be Taught?: A New Model of Business Ethics Education. Journal of Business Ethics, 17(9/10), 965-977.

Lucas, R., \& Mason, N. (2008). A survey of ethics and regulation within the ICT industry in Australia: ethics education. Journal of Information, Communication and Ethics in Society, 6(4), 349-363. doi: doi:10.1108/14779960810921141

Lucas, R., \& Weckert, J. (2008). Regulation in the ICT industry. Canberra: Centre for Applied Philosophy and Public Ethics, Australian National University.

Manders-Huits, N. (2010). What values in design? A critical analysis of value-sensitive design. Science and Engineering Ethics, 17(2), 271-287.

MacIntyre, M. (1984). After Virtue, University of Notre Dame Press, Notre Dame, Ind.

May, D. R., Luth, M. T., \& Schwoerer, C. E. (2014). The Influence of Business Ethics Education on Moral Efficacy, Moral Meaningfulness, and Moral Courage: A Quasi-experimental Study. Journal of Business Ethics, 124(1), 67-80. doi: 10.1007/s10551-013-1860-6

Moore, G. (2003). Hives and horseshoes, Mintzberg or MacIntyre: what future for corporate social responsibility? Business Ethics: A European Review, 12(1), 41-53. doi: 10.1111/1467-8608.00304

Mullerat, R. (2013). Professional Ethics, What For . . ? Ramon Llull Journal of Applied Ethics, $4,173-199$.

Neusner, J., \& Chilton, B. (1997). The intellectual foundations of Christian and Jewish discourse: The philosophy of religious argument. London: Routledge.

Patton, M. Q. (2002). Qualitative research and evaluation methods (3 ed.). Thousand Oaks, CA: Sage.

Phillips, R. A., \& Margolis, J. D. (1999). Toward an ethics of organizations. Business Ethics Quarterly, 9(4), 619-638.

Rogerson, S., Weckert, J., \& Simpson, C. (2000). An ethical review of information systems development - The Australian Computer Society's code of ethics and SSADM. Information Technology and People, 13(2), 121-136. doi: doi:10.1108/09593840010339853

Rosenstand, N. (2006). The Moral of the Story: An Introduction to Ethics. New York: McGraw-Hill. 
Russell, B. (1972). A History of Western Philosophy. New York: Simon \& Schuster.

Simpson, C., Nevile, L., \& Burmeister, O. K. (2003). Doing Ethics: A Universal Technique in an Accessibility Context. Australasian Journal of Information Systems, 1O(2).

Venable, J. R., Pries-Heje, J., Bunker, D., Russo, N. L., Johri, A., \& Nair, S. (2011). The role of design values in information system development for human benefit. Information Technology and People, 24(3), 281-302. doi: doi:10.1108/09593841111158383

WSIS+10. (2014). WSIS+10 High-Level Event: Open Consultation Process Multistakeholder Preparatory Platform, Draft Final Report.

Copyright: (C) 2017 Al-Saggaf, Burmeister \& Schwartz. This is an open-access article distributed under the terms of the Creative Commons Attribution-NonCommercial 3.0 Australia License, which permits non-commercial use, distribution, and reproduction in any medium, provided the original author and AJIS are credited.

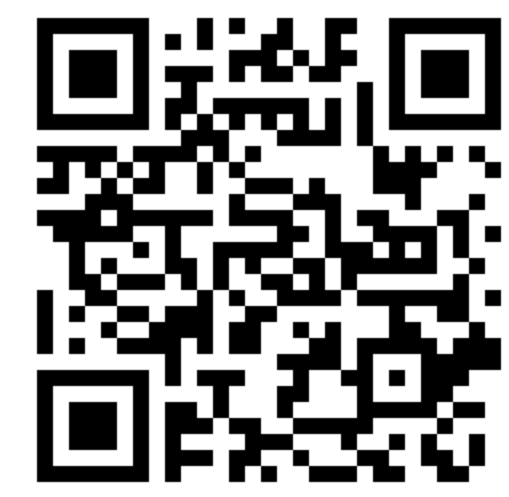

